\title{
Relationships between reproduction in suspension- feeding hard clams Mercenaria mercenaria and phytoplankton community structure
}

\author{
Roger I. E. Newell ${ }^{1, *}$, Stephen T. Tettelbach ${ }^{2}$, Christopher J. Gobler ${ }^{3}$, \\ David G. Kimmel ${ }^{4}$ \\ ${ }^{1}$ Horn Point Laboratory, University of Maryland Center for Environmental Science, PO Box 775, Cambridge, \\ Maryland 21613, USA \\ ${ }^{2}$ Biology Department, Long Island University, Brookville, New York 11548, USA \\ ${ }^{3}$ School of Marine and Atmospheric Sciences, Stony Brook University, Stony Brook, New York 11794-5000, USA \\ ${ }^{4}$ Department of Biology/Institute for Coastal Science and Policy, East Carolina University, Greenville, \\ North Carolina 27858, USA
}

\begin{abstract}
We hypothesized that the decline in hard clam Mercenaria mercenaria populations since the 1970s in many of the south shore bays of Long Island, New York, USA, was due to changes in reproduction caused by variations in phytoplankton available as a food resource. We measured in 2000 and 2001 the reproductive condition of female clams from 5 sites in south shore bays of Long Island and from 2 sites in New Jersey. Phytoplankton composition was measured as the concentration of total and size-fractionated chlorophyll a ( $\mathrm{chl} \mathrm{a),} \mathrm{particulate} \mathrm{organic} \mathrm{carbon} \mathrm{(POC),} \mathrm{and} \mathrm{nitrogen}$ (PON), and the abundance of the harmful picoplankter Aureococcus anophagefferens. Timing of peak hard clam reproduction was nearly identical across sites, and was the same as in archived samples of clams collected in 1978 and 1979. Hard clam condition index differed between sites, with poorest condition being exhibited at the 3 Great South Bay (GSB) sites. There were also appreciable differences in relative reproductive output between locations, with clams again from the 3 GSB sites having the lowest estimated egg production. The central and eastern GSB had the highest levels of total chl $a$, POC, and PON, however, of any south shore bay, although this was mainly contributed by cells $<2 \mu \mathrm{m}$, which have low nutritional value for adult hard clams. In addition, the 3 sites in GSB suffered brown tide blooms during 2000 and 2001, which are known to inhibit bivalve feeding. We conclude that changes in the composition of the phytoplankton community at some locations may be reducing hard clam reproductive output.
\end{abstract}

KEY WORDS: Hard clam · Phytoplankton composition $\cdot$ Brown tide $\cdot$ Reproduction $\cdot$ Aureococcus anophagefferens $\cdot$ Mercenaria mercenaria

\section{INTRODUCTION}

Coastal ecosystems have been subject to increasing anthropogenic nutrient loadings in recent decades, leading to changes in the phytoplankton communities that form the major basis of marine food webs (Nixon 1995, Cloern 2001). These changes are manifest as an increase in rates of phytoplankton production, often leading to measurable increases in the concentration of chlorophyll a (chl a) in the water column (Cloern 2001). In addition, changes in the amount, timing, and chemical form of the nutrients entering the receiving waters can directly alter the species composition of the phytoplankton community. Such changes may include reduced abundances of diatoms relative to dinoflagellate species (Smayda 1990, Cloern 2001) and an increase in monospecific algal blooms (Cloern 2001). These blooms may be of species classified as 'harmful', 
which are capable of producing toxins that can have a directly adverse effect on secondary consumers (Shumway 1990, Cloern 2001, Anderson et al. 2002, Sunda et al. 2006). In addition to these direct effects, monospecific blooms reduce the diversity of phytoplankton species available as nutritious food for secondary consumers, such as suspension-feeding bivalve molluscs.

The south shore bays (SSB) of Long Island, New York, USA, are lagoons with relatively long residence times that make them particularly susceptible to the adverse effects of nutrient enrichment (Wilson et al. 1991). There have been marked changes in the phytoplankton species composition over the last 3 decades in these bays (Lively et al.1983, Sieracki et al. 2004, Gobler et al. 2005, Lonsdale et al. 2006). Lively et al. (1983) reported that phytoplankton communities in the late 1970 s were composed of a mixed assemblage, with 2 to $4 \mu \mathrm{m}$ diameter chlorophytes comprising $~ 50 \%$ of standing crop biomass. Since then, small species have come to dominate phytoplankton communities in SSB (picoplankton $>90 \%$ of biomass during summer; Sieracki et al. 2004, Lonsdale et al. 2006), and harmful brown tides caused by the picoplanktonic pelagophyte Aureococcus anophagefferens have occurred on a near annual basis (Bricelj \& Lonsdale 1997, Gobler et al. 2005). This picoplankter has direct, toxic effects on suspension-feeding bivalves, reducing the feeding (Tracey 1988, Bricelj et al. 2001) and growth (Bricelj \& Lonsdale 1997, Grizzle et al. 2001, Bricelj et al. 2004, Wazniak \& Glibert 2004, Padilla et al. 2006, Bricelj \& MacQuarrie 2007) of all life stages of hard clams. Finally, these bays have been characterized by a large degree of variability in patterns of primary production. For example, Lively et al. (1983) reported that chl a concentrations and rates of algal production in Great South Bay were about 3 times lower in April to May than in July and August. They also observed extreme interannual differences in chl a concentrations (e.g. $20 \mathrm{\mu g} \mathrm{l}^{-1}$ in June 1979, but close to zero in June 1980).

Concurrent with these changes in the phytoplankton community, there has been a decline in stocks of the hard clam Mercenaria mercenaria, particularly in the largest south shore estuary on Long Island, Great South Bay (GSB) (Kassner 2000). Commercial hard clam harvests for GSB averaged 3248 metric tons (t) meat weight $\mathrm{yr}^{-1}$ between 1970 and 1979, and this declined by $97 \%$ to an average of $91 \mathrm{t} \mathrm{yr}^{-1}$ from 1996 to 2007 (NYSDEC 2008). Overharvesting in GSB is thought to have been largely responsible for this tremendous decline in hard clam populations through the late 1970s and early 1980s (Kraeuter et al. 2005). However, despite greatly reduced harvesting pressure, hard clam stocks continued to decline through the 1990s, due in part to reduced recruitment after
1995 (Kraeuter et al. 2005). Not all SSBs are suffering from declining hard clam stocks, as clams are still abundant in Hempstead Bay. In nearby Sandy Hook Bay, New Jersey, USA, near the mouth of the Hudson River, populations fluctuated at low levels in the 1970s and 1980s. Stocks increased dramatically in the early 1990s and supported harvest levels well above those in GSB through the 1990s and early 2000s; e.g. between 1994 and 2000, annual harvests averaged $346 \mathrm{t}$ (MacKenzie et al. 2002, MacKenzie 2003, Zimmer 2004).

Changes in the abundance, species composition, or timing of phytoplankton blooms can alter the quantity and quality of the food available to the suspensionfeeding hard clams. Such changes in food supply may reduce the energy available to adult hard clams at critical times for partitioning into germinal production, thereby reducing overall reproductive output (Bayne 1975 , 1976) or altering the time of peak reproductive condition and spawning (Newell et al. 1982). Kassner \& Malouf (1982) reported variation in the temporal pattern of gametogenesis and spawning for hard clams in GSB between 1978 and 1979, which they speculated may have been caused by variability in the timing of phytoplankton blooms (Lively et al. 1983). If patterns of primary production continue to be temporally and spatially variable in GSB, then a plausible scenario for the continuing decline in hard clam recruitment is that adult clams are obtaining insufficient food during the crucial spring period (Eversole 2001) to sustain a normal reproductive cycle. In support of this hypothesis, Laetz (2002) found from analysis of internal shell growth rings that hard clams collected from locations subject to brown tides exhibited a lower rate of shell growth than those from non-brown-tide locations. A corollary of reduced growth is that clams will likely have less energy available for reproduction. Alternatively, the occurrence of harmful brown tide blooms may also be disrupting the timing or success of gametogenesis of hard clams. Either scenario would reduce clam recruitment in the affected bays, and therefore may be one of the major mechanism(s) to explain the observed decline in hard clam growth and stock abundance.

In the present paper we tested the hypothesis that variation in hard clam reproduction at different locations in the SSBs of Long Island is associated with either changes in the species composition of the phytoplankton community or the seasonal pattern of phytoplankton abundance. We used quantitative histological techniques to assess the reproductive condition of adult hard clams collected over an annual cycle from locations in each of 3 major SSBs. We concurrently measured phytoplankton community structure so that we could link location-specific hard clam reproductive 
processes to prevailing food availability. We also collected hard clams from reference sites in Sandy Hook Bay, where abundant stocks currently support a robust fishery.

\section{MATERIALS AND METHODS}

Hard clam sampling. Hard clams Mercenaria mercenaria were collected from 5 sites along the south shore of Long Island, New York, USA (Table 1, Fig. 1); 1 site in Shinnecock Bay, 3 sites in Great South Bay, and 1 site in Middle Bay (the middle of Hempstead Bay's 3 basins). Middle Bay was selected to represent a Long Island site where brown tide blooms are not known to occur. For comparison, we obtained hard clams from 2 reference sites in Sandy Hook Bay, near the mouth of the Hudson River, New Jersey, USA (Table 1, Fig. 1). All sampling sites were selected to correspond closely to sites routinely sampled by various municipal agencies for total chl $a$, cell counts for brown tide Aureococcus anophagefferens, water temperature, and salinity.

At each of our 7 sites, $\sim 70$ adult hard clams $(\geq 40$ to $125 \mathrm{~mm}$ shell length; Table 1) were collected on each of 11 to 13 dates between October 2000 and September 2001. Hard clams were collected approximately every 3 wk during autumn and spring periods and approximately every 2 wk between late June and midSeptember 2001; no samples were taken during the reproductively quiescent winter period between midNovember and mid-March. Clams were obtained within 100 to $150 \mathrm{~m}$ of the listed latitude and longitude coordinates (Table 1). For logistical reasons, hard

Table 1. Mercenaria mercenaria. Location and range of depths at mean low water (m) for the 7 sites where hard clams and water samples were collected. Sandy Hook Bay site names correspond to those of the New Jersey Dept. of Environmental Protection. Total number of hard clams examined over the course of the study, percentage of these identified as male and female $(\%$ of each gender does not sum to $100 \%$ because some clams were hermaphrodite), and mean \pm SD shell length are given for each site. Hard clam shell length varied significantly between sites (ANOVA $;$ represent sites that had statistically different $(\mathrm{p}<0.05)$ mean clam lengths. GSB: Great South Bay

\begin{tabular}{|lcccccccc|}
\hline Site & $\begin{array}{c}\text { Latitude } \\
(\mathrm{N})\end{array}$ & $\begin{array}{c}\text { Longitude } \\
(\mathrm{W})\end{array}$ & $\begin{array}{c}\text { Depth } \\
(\mathrm{m})\end{array}$ & $\begin{array}{c}\text { No. of } \\
\text { clams }\end{array}$ & $\begin{array}{c}\text { Male } \\
(\%)\end{array}$ & $\begin{array}{c}\text { Female } \\
(\%)\end{array}$ & $\begin{array}{c}\text { Mean shell length } \\
(\mathrm{mm})\end{array}$ & $\begin{array}{c}\text { Bonferroni } \\
\text { grouping }\end{array}$ \\
\hline Shinnecock Bay & $40^{\circ} 50.6^{\prime}$ & $72^{\circ} 32.1^{\prime}$ & $2-3$ & 943 & 54 & 45 & $77.3 \pm 14.3$ & $\mathrm{C}$ \\
Eastern GSB & $40^{\circ} 44.3^{\prime}$ & $73^{\circ} 01.6^{\prime}$ & 3 & 985 & 52.5 & 46.0 & $54.8 \pm 7.0$ & $\mathrm{~A}$ \\
Central GSB & $40^{\circ} 42.4^{\prime}$ & $73^{\circ} 14.9^{\prime}$ & $1.5-2.5$ & 935 & 48.2 & 51 & $63.3 \pm 12.9$ & $\mathrm{~B}$ \\
Western GSB & $40^{\circ} 39.9^{\prime}$ & $73^{\circ} 21.3^{\prime}$ & $2-3$ & 939 & 46.9 & 52.1 & $84.9 \pm 15.7$ & $\mathrm{D}$ \\
Middle Bay & $40^{\circ} 35.9^{\prime}$ & $73^{\circ} 35.7^{\prime}$ & $1-3$ & 796 & 52.9 & 44.8 & $76.7 \pm 16.6$ & $\mathrm{C}$ \\
Sandy Hook Bay 906A & $40^{\circ} 25.2^{\prime}$ & $74^{\circ} 00.2^{\prime}$ & $5-7$ & 881 & 47.3 & 50.5 & $65.9 \pm 13.6$ & $\mathrm{~B}$ \\
Sandy Hook Bay 918 & $40^{\circ} 27.4^{\prime}$ & $74^{\circ} 02.3^{\prime}$ & $5-7$ & 868 & 50.1 & 49.1 & $66.3 \pm 12.4$ \\
\hline
\end{tabular}

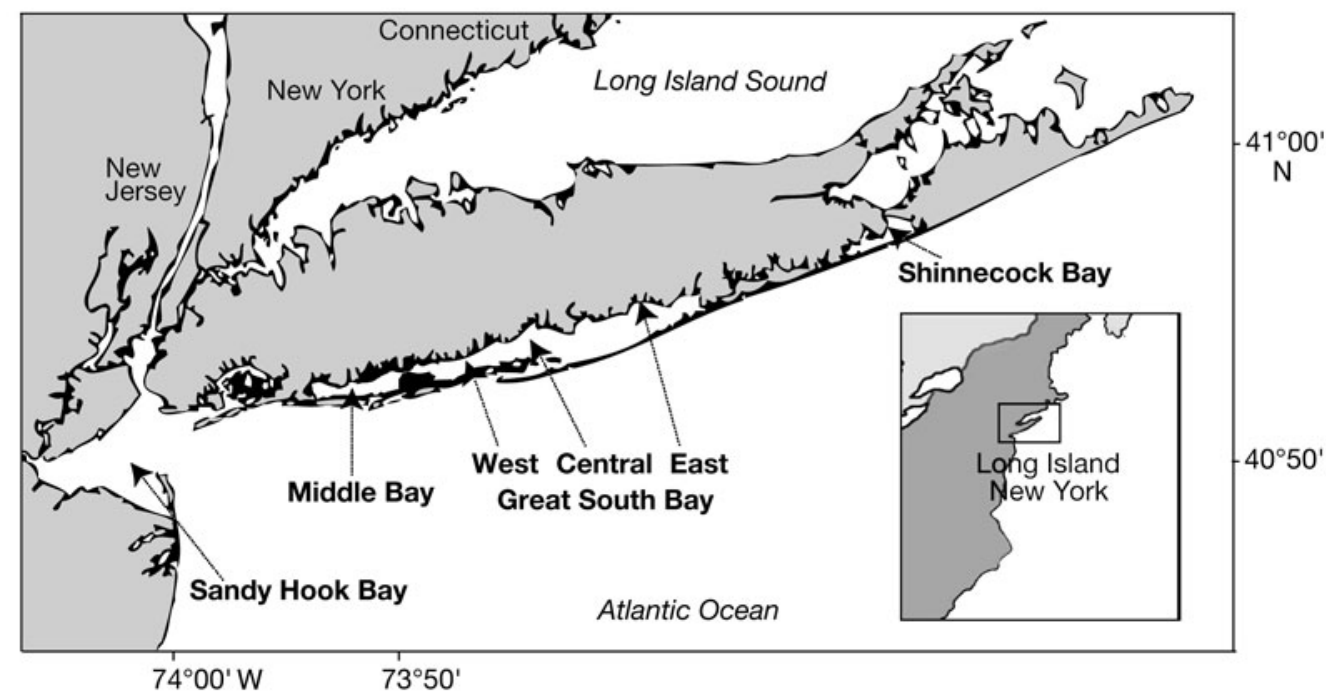

Fig. 1. Location of 5 hard clam Mercenaria mercenaria sampling sites on the south shore of Long Island, New York, and 2 sites in Sandy Hook Bay (see Table 1 for geographical coordinates), New Jersey, USA 
clams from the 2 Sandy Hook Bay sites were collected by a commercial clam harvester and shipped overnight to our laboratory.

Hard clam analyses. Shell lengths and whole live weights (shell plus contained tissues) were measured for each hard clam. Clams were opened and the gender was determined by microscopically (40 to $100 \times$ ) examining a small tissue sample from the gonad for the presence of either eggs or sperm. Histological reproductive analyses were conducted solely on female clams in order to obtain the most accurate link between food availability and gametogenic condition. For 15 female clams, the foot and contained visceral mass was cut at the dorsal edge and placed into Davidson's fixative for $48 \mathrm{~h}$ at $4^{\circ} \mathrm{C}$. After fixing, a $\sim 1 \mathrm{~cm}$ thick segment of tissue was cut with a razor blade from the dorsal edge of the foot/visceral mass. This tissue is routinely used to assess the reproductive condition of hard clams (e.g. Kassner \& Malouf 1982). After a further $48 \mathrm{~h}$ in Davidson's fixative, individual tissue segments were placed into plastic cassettes and stored in $70 \%$ ethanol. Tissues were then processed through an ascending alcohol series, embedded in paraplast paraffin wax, sectioned at $6 \mu \mathrm{m}$, and stained with hematoxylin and eosin according to standard histological techniques (Bayne et al. 1985). The reproductive condition of female clams was assessed using stereological point counting (Bayne et al. 1985). This method involves using a microscope eyepiece 'Weibel screen' to superimpose a 50-point grid across the field of view of the stained tissue section. The number of points of intersection between germinal tissues were counted, and this value was expressed as a percentage of the total possible (50). The results were expressed as a gamete volume fraction (GVF), which is the percent volume of the sampled tissue that was comprised of germinal tissue. This technique is more accurate than traditional gonad indices (Eversole 2001), which result in nominal rather than interval measurements (Bayne et al. 1985). In order to assess if hard clam reproductive cycles had changed over a decadal time scale, we used the same methods to analyze histological slides of hard clams originally collected in 1979 by Kassner (1982). Kassner prepared slides separately for different size classes of hard clams collected from a site in the eastern GSB that was close to our sampling site. On only 8 sampling occasions between April and July 1979 were an adequate number of clams $(n>5)$ collected to enable us to analyze individuals in the 30 to $48 \mathrm{~mm}$ shell length category.

For an additional 20 clams (10 female, 10 male) of a range of shell sizes ( 40 to $110 \mathrm{~mm}$ ), we removed the entire soft tissues and determined dry tissue weights (g) after oven drying at $80^{\circ} \mathrm{C}$ for $\geq 2 \mathrm{~d}$. The condition index $(\mathrm{CI})$, which reflects the degree to which a clam was adding somatic and germinal tissue in relation to shell size, was determined using the formula (Crosby \& Gale 1990):

$$
\mathrm{CI}=\frac{\text { Total dry tissue wt }}{(\text { Total live wet wt }- \text { dry shell } \mathrm{wt})} \times 100
$$

Phytoplankton sampling. Water samples for seston analysis were collected from $\sim 15 \mathrm{~cm}$ beneath the water surface, concurrently with hard clam sampling at all SSB sites. The well-mixed nature of these systems (Wilson et al. 1991) assured these samples were representative of the whole water column. For chl a (total and size-fractionated) concentrations, 3 replicate pairs of $60 \mathrm{ml}$ water samples were taken in a plastic syringe. For a given sample pair, 1 sample was passed through a Whatman GF/F filter for total chl a analysis. The second $60 \mathrm{ml}$ sample was used for determination of $\mathrm{chl} a$ size fractions. This water was first passed through a Swinex water filtration cartridge fitted with $5 \mu \mathrm{m}$ Nitex mesh screen, after which $60 \mathrm{ml}$ of air was slowly injected through the same cartridge, thereby passing any remaining water through the screen. The filtrate was injected through 2 filter cartridges, in series; the first with a $2 \mu \mathrm{m}$ filter and the second with a $0.7 \mu \mathrm{m}$ Whatman GF/F filter; air was subsequently injected, as above. In this way, we obtained chl a measurements of the following size fractions: 0.7 to $2 \mu \mathrm{m}, 2$ to $5 \mu \mathrm{m}$, and $>5 \mu \mathrm{m}$ (the $>5 \mu \mathrm{m}$ value was obtained by subtraction of the values for the 2 smaller fractions from the total chl a value obtained for the parallel replicate sample). In cases where the water at a given site was visually judged to have low total seston levels at the time of sampling, a total volume of $120 \mathrm{ml}$ (from two $60 \mathrm{ml}$ syringe samples) was used for both the total and fractionated chl a samples. Filters were folded in half, wrapped in aluminum foil, and placed on ice for transport to the laboratory, where they were stored at $-80^{\circ} \mathrm{C}$. Chl a concentrations on these filters were determined using standard fluorometric methods (Strickland \& Parsons 1972).

For all sites except the 2 in Sandy Hook Bay, water samples were also taken in triplicate for determination of seston organic carbon and nitrogen content. A plastic syringe was used to pass a known volume of water through a previously heat-treated $\left(450^{\circ} \mathrm{C}\right.$ for $\left.4 \mathrm{~h}\right)$, $25 \mathrm{~mm}$ Whatman GF/C filter (greater than $\sim 1.2 \mu \mathrm{m}$ effective particle size retention) held in a Swinex water filtration cartridge. Individual filters were folded in half, placed inside a Polychron plastic envelope, and stored on ice for transport to the laboratory, where they were stored at $-80^{\circ} \mathrm{C}$ until analysis for total organic carbon and nitrogen (Exeter EAI CE-440 Elemental Analyzer).

Three replicate $9 \mathrm{ml}$ samples were collected from beneath the water surface at all SSB sites on each sam- 
pling date, for determination of Aureococcus anophagefferens concentrations. Samples were fixed immediately with glutaraldehyde (1\% final concentration), placed on ice, and refrigerated at $4^{\circ} \mathrm{C}$ upon return to the laboratory. Subsamples from replicate water samples were gently filtered $(<5 \mathrm{kPa})$ onto a $0.8 \mu \mathrm{m}$ black polycarbonate filter, and stained with an immunofluorescent label (Anderson et al. 1989), and the number of A. anophagefferens cells was enumerated via epifluorescent microscopy. We used concentrations of the primary and secondary antibodies that were 2-fold higher than those originally used by Anderson et al. (1989). A minimum of 100 cells was counted per sample, in at least 10 fields of view, to yield a relative standard deviation of $14 \%$ for replicate counts of the same sample $(\mathrm{n}=6)$ at cell densities of $10^{5}$ cells $\mathrm{ml}^{-1}$. To ensure the accuracy of our immunofluorescent technique, we compared it to counts performed with a hemocytometer on a light microscope. The 2 techniques yielded statistically identical results (ANOVA, $\mathrm{p}>0.05$ ) using cultured $A$. anophagefferens Clone CCMP1708 at cell densities of $\sim 10^{5}$ cells ml ${ }^{-1}$.

For the 2 Sandy Hook Bay sites, whole water samples were collected from $\sim 15 \mathrm{~cm}$ beneath the water surface, concurrently with clam collection at each sampling site, and stored on ice. This water was processed within $24 \mathrm{~h}$ of collection as described above for total and size fractionated chl a and Aureococcus anophagefferens cell counts. No carbon and nitrogen seston samples were processed for Sandy Hook Bay.

We analyzed monitoring data available from local resource agencies to obtain a longer term perspective on water quality and phytoplankton abundance at our various sites. Such an analysis was facilitated by the fact that we had purposely positioned our hard clam study sites in close proximity to official water-quality monitoring locations. Water-quality data for Sandy Hook Bay were obtained for the years 1991 to 2002 from the New Jersey Department of Environmental Protection, and for Middle Bay, from the Town of Hempstead Department of Conservation and Waterways for the years 1975 to 2001. Data for all other sampling locations were obtained from Suffolk County Department of Health Services, Office of Ecology, for the years 1988 to 2002. There were no long-term temporal trends in the parameters (total chl $a$, temperature, salinity) at each site during the time periods we examined, and thus seasonal means were determined for each site.

Statistical analyses. Data were analyzed using the SPLUS (Insightful) statistical analysis program. Prior to analysis, all data were tested for normality using the Kolmogorov-Smirnov goodness-of-fit test (Zar 1999), and data that were non-normal, including percentage values, were transformed using Box-Cox equations (Box \& Cox 1964). In order to provide sufficient data to make statistically valid comparisons between sites, data were aggregated into 4 seasons that correspond to important processes in the hard clam reproductive cycle (i.e. samples collected between 1 December and 28 February were labeled winter; March through May, as spring; June through August, as summer; and September through November, as autumn).

Shell lengths for all hard clams collected at each site (5 different locations in the SSBs and 2 different locations in Sandy Hook Bay) were compared using analysis of variance (ANOVA). Following ANOVA analyses, we performed post hoc, multiple-comparison tests (Bonferroni; Zar 1999) to determine which sites had significant differences in clam size. The CI and shell length relationships between seasons and sites were compared using multiple linear regression.

We compared GVF and CI between the 7 sites for the spring, summer, and autumn seasons using a 2-way ANOVA to test for significant effects, or interaction, of site and/or season. These analyses also included GVF data from the hard clams collected by Kassner (1982) in the eastern GSB, to provide a decadal time-scale comparison, resulting in a total of 8 sites for this comparison. Type III sums of squares were used in the ANOVA analyses due to unequal numbers of observations for some sites and seasons. Our null hypothesis was that there was no difference in GVF or CI between sites. Following the ANOVA analyses, we performed post hoc, multiple-comparison tests (Tukey's test; Zar 1999) to determine which sites or seasons had significant differences in GVF or CI.

Chl a data were divided into 4 separate sets of observations: $>0.7 \mu \mathrm{m}$ (total), $>5 \mu \mathrm{m}$ size fraction, 2 to $5 \mu \mathrm{m}$ size fraction, and 0.7 to $2 \mu \mathrm{m}$ size fraction. For each set of observations, we performed ANOVA analyses and multiple-comparison tests as described above for GVF and CI, using all available seasons. Our null hypothesis was that there was no difference in total chl $a$, in the $>5 \mu \mathrm{m}$ size fraction, 2 to $5 \mu \mathrm{m}$ size fraction, or 0.7 to $2 \mu \mathrm{m}$ size fraction of chl a between the 7 sites or between the 3 seasons.

\section{RESULTS}

There was significant variation (ANOVA, p < 0.001) in the shell length of hard clams Mercenaria mercenaria collected over the course of the study among the 7 sites, although there was no discernible pattern to this variation (Table 1). Clams from the eastern GSB were significantly smaller than clams from all other sites, and clams from the western GSB were significantly larger $(84.9 \mathrm{~mm})$ than those from all other sites (Bonferroni test, $\mathrm{p}<0.05$ ). In order to examine if these differences in mean size could influence the compar- 

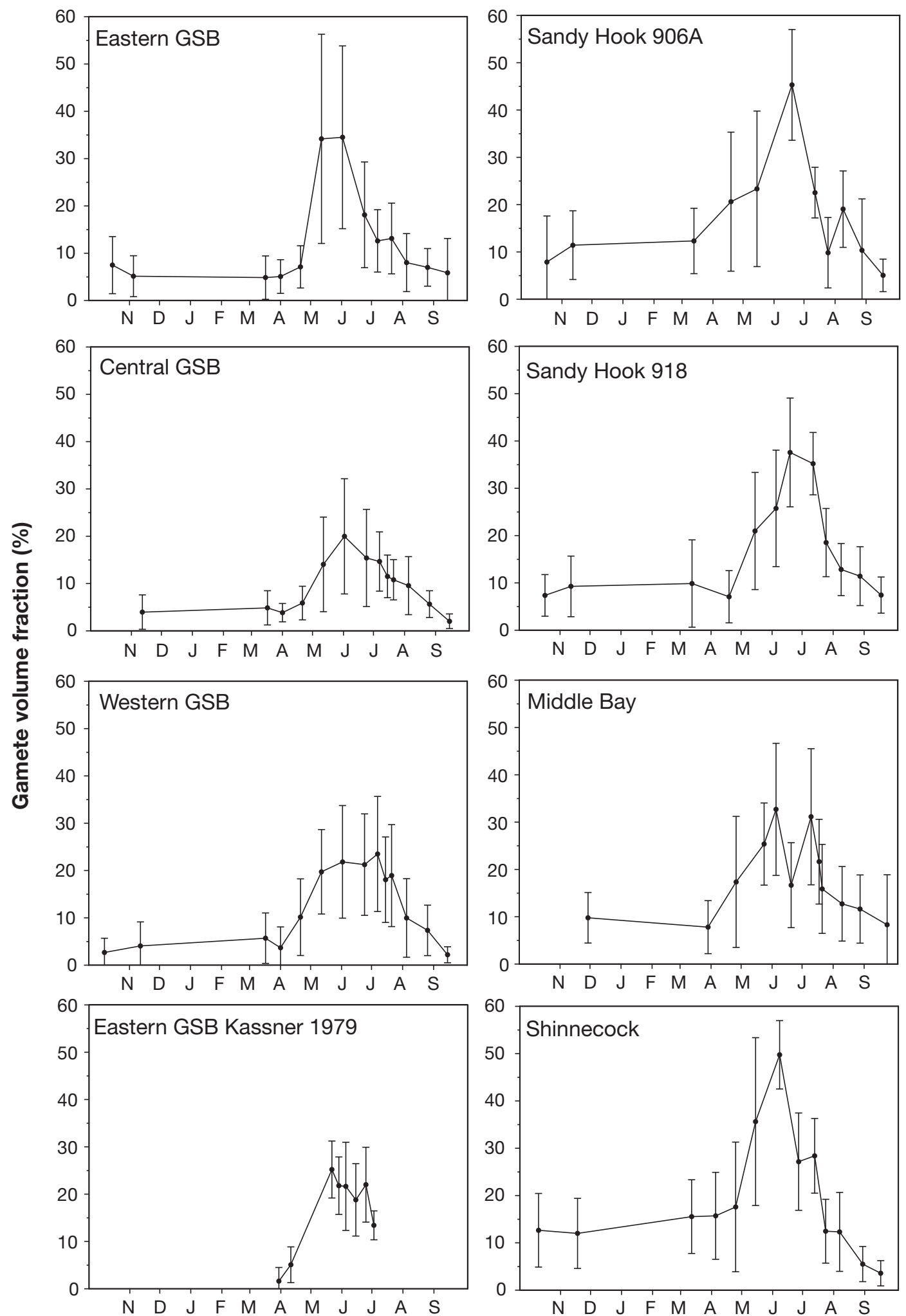

Time (mo)

Fig. 2. Mercenaria mercenaria. Female reproductive condition (\% gamete volume fraction) from the 5 sampling sites on the south shore of Long Island and 2 sites in Sandy Hook Bay during 2000 and 2001. Also plotted are data for clams measuring 30 to $48 \mathrm{~mm}$ in shell height collected in 1979 from the eastern Great South Bay (GSB) by Kassner (1982). Each point is the mean \pm SD of 15 clams 
isons of CI and GVF between sites, we regressed CI against shell length by site and by season. We found that overall there was no significant relationship between CI and shell size for any season (spring: $\mathrm{r}^{2}=$ 0.04; summer: $r^{2}=0.002$; spring: $r^{2}=0.05$ ), with the slope of the regression line not differing appreciably from zero. This lack of a relationship between CI and shell size for hard clams of the size we collected allowed us to compare CI data among sites, despite the variation in the size of hard clams we collected.

The sex ratio of the clams sampled from all 7 locations was close to the expected 50:50 ratio in this dioecious animal (Table 1). The annual cycle of reproductive condition, measured as GVF for female hard clams from all 7 sampling sites, exhibited a peak in gamete abundance in June and July (Fig. 2). ANOVA revealed that GVF differed between sites $(F=17.64, \mathrm{p}<0.001)$ and season $(F=129.6, \mathrm{p}<0.001)$. An interaction between site and season was also significant $(F=2.37$, $\mathrm{p}=0.004)$. This interaction meant that the individual effects of site or season could not be compared independently. We then performed a 1-way ANOVA for site only, to examine the individual effects of these variables. A multiple-comparison test revealed that the western, central and eastern GSB had significantly lower (Tukey's test, p < 0.05) GVF than clams from Shinnecock, Middle Bay, and Sandy Hook sites. (The results for the multiple-comparison test are presented in Table $\mathrm{S} 1$ in the Supplement available at: http:// www.int-res.com/journals/suppl/m387p179_app.pdf). A multiple-comparison test also revealed that the GVF in summer was significantly higher than the values spring and autumn, and those from spring were significantly higher than those from autumn (Tukey's test, $\mathrm{p}<0.05)$.

The CI for hard clams from Middle Bay, Shinnecock Bay, and Sandy Hook Bay were $~ 50 \%$ higher than that for hard clams from sites in GSB (Fig. 3; mean CI \pm SD by date and sampling site are presented in Table S2, and results for the multiplecomparison test are presented in Table S3, both tables are in the Supplement available at: http://www.int-res.com/journals/suppl/ m387p179_app.pdf). The CI of clams also varied seasonally, with a late spring to summer peak across most sites (Fig. 3). ANOVA revealed that the CI differed between sites $(F=132.49, \mathrm{p}<0.001)$ and seasons $(F=$ 41.57, $\mathrm{p}<0.001)$, and the interaction between site and season was also significant $(F=6.13, \mathrm{p}<0.001)$. We then performed separate 1-way ANOVAs for season only and site only, to examine the individual effects of these variables. The CI of clams from the western, central, and eastern GSB were significantly lower (Tukey's test, $\mathrm{p}<0.05)$ than that for clams from Shinnecock, Middle Bay, and Sandy Hook sites. Hard clams from Middle Bay had a significantly greater (Tukey's test, $\mathrm{p}<0.05) \mathrm{CI}$ than clams from all other sites. A multiplecomparison test among seasons found the CI for hard clams in summer was significantly higher than those in spring and autumn, although the CI for these 2 seasons did not differ significantly (Tukey's test, $\mathrm{p}<0.05$ ).

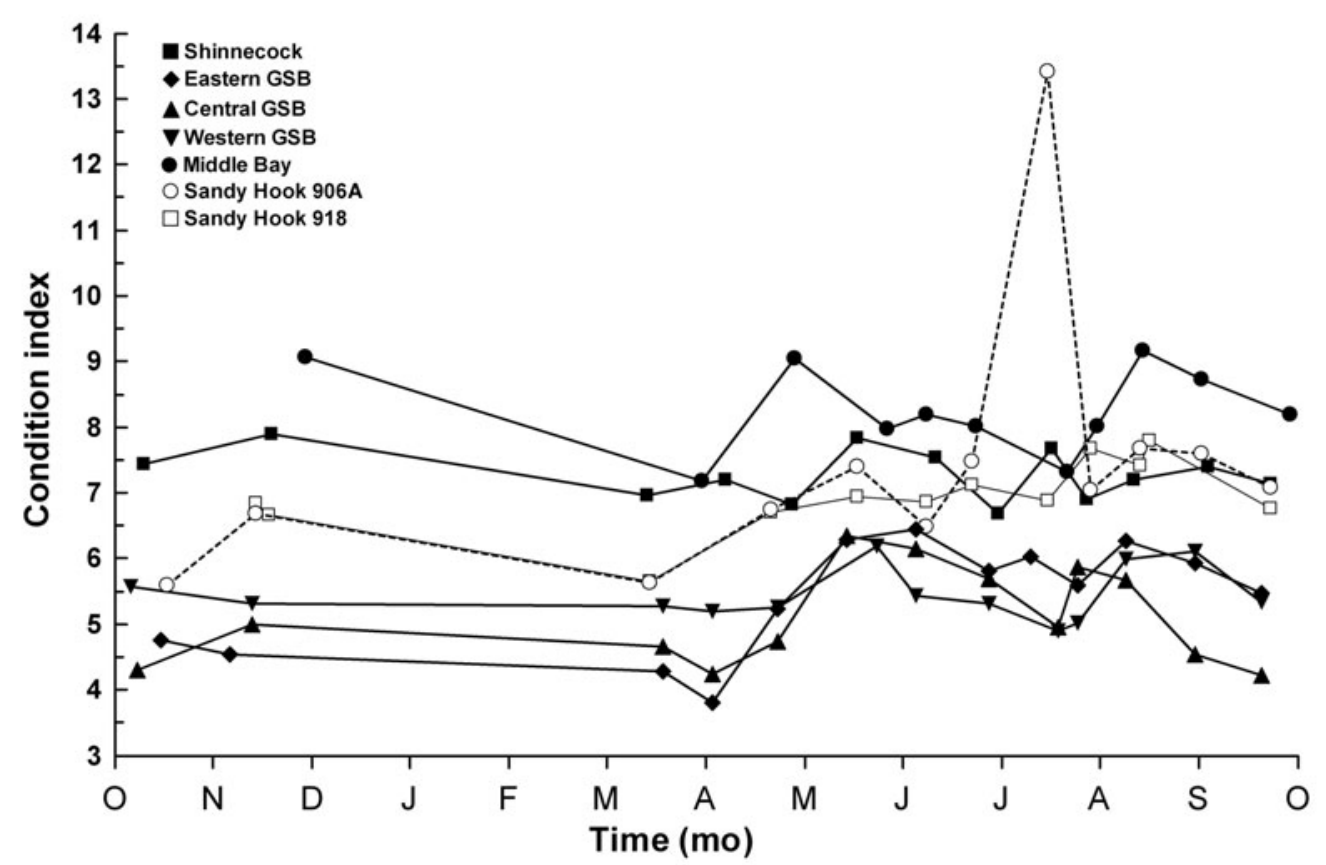

Fig. 3. Mercenaria mercenaria. Condition index (\%) from the 5 sampling sites on the south shore of Long Island and 2 sites in Sandy Hook Bay during 2000 and 2001. Each point is the mean of 15 clams. Error bars have been omitted for clarity. GSB: Great South Bay 
We estimated the germinal production for female hard clams at the various sampling times by multiplying the GVF values by the CI values to produce an index we call the 'relative reproductive output' (RRO) (Fig. 4). In order to compare changes in RRO between the 7 sites we integrated the area under the line fitted to the reproductive output versus time graph (Fig. 4). We used the values for March to late April and late September to November sampling times as the base- line and integrated the area under the curves above this baseline. This baseline was selected from visual inspection of the GVF curves (Fig. 4) as the time when the hard clams were consistently exhibiting their lowest reproductive output before and after the summer peak in reproduction. The 3 sites with the highest total RRO during summer 2001 were the 2 reference sites in Sandy Hook Bay (RRO = 200 and 144) and Middle Bay $(\mathrm{RRO}=164)$ (Fig. 5). These 3 sites had total RRO values

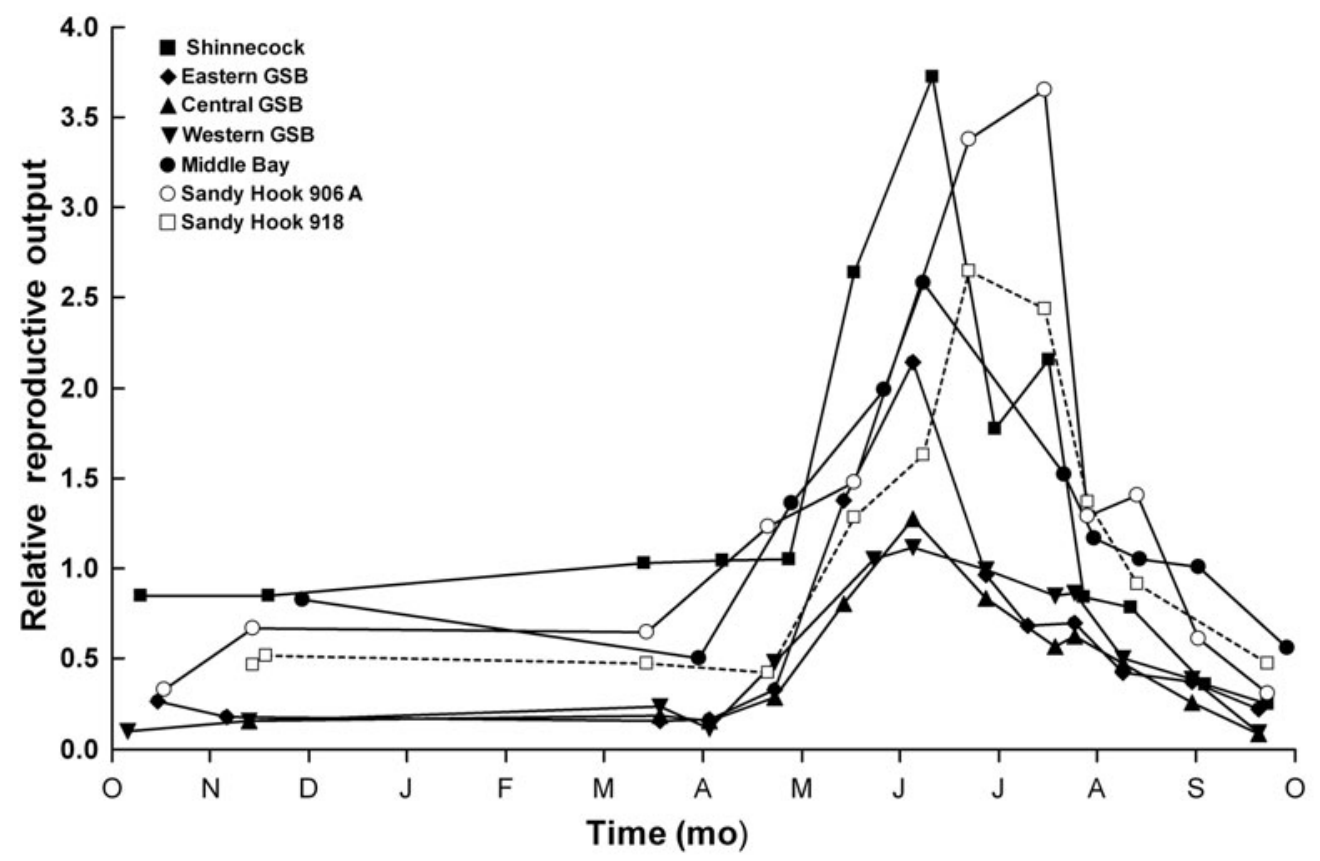

Fig. 4. Mercenaria mercenaria. Relative reproductive output, calculated by multiplying the mean reproductive condition (Fig. 2) by the mean condition index value (Fig. 3) for the same time point, for female hard clams at the 5 sampling sites on the south shore of Long Island and 2 sites in Sandy Hook Bay during 2000 and 2001. GSB: Great South Bay

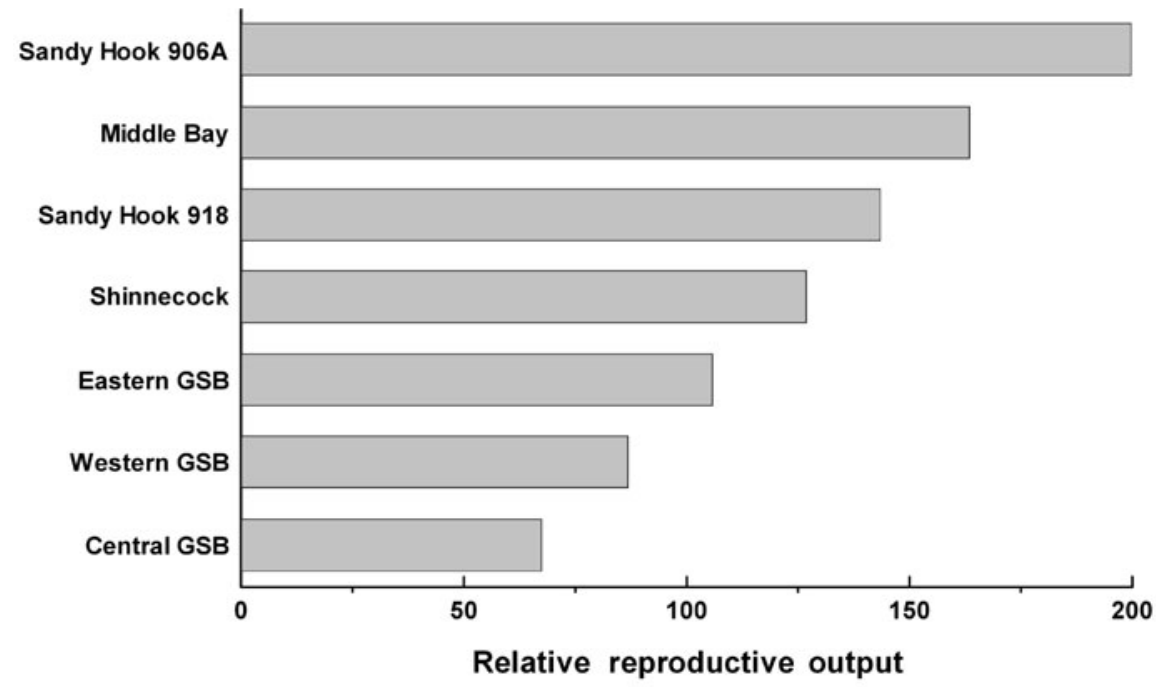

Fig. 5. Mercenaria mercenaria. Total relative reproductive output for summer 2001, for female hard clams at the 5 sampling sites on the south shore of Long Island and 2 sites in Sandy Hook Bay. GSB: Great South Bay 
that were about twice that of the central GSB (RRO = 68) and western (RRO = 87) GSB sites, which exhibited the lowest values. The total reproductive output values of 129 and 106 for hard clams from Shinnecock and the eastern GSB, respectively, were intermediate between these extremes.

Mean \pm SD concentrations of chl a for the various size fractions by date and sampling site are presented in Table S4 in the Supplement available at: http:// www.int-res.com/journals/suppl/m387p179_app.pdf. The total chl a concentrations in whole water from each season in 2000 and 2001 (Table 2) differed between sites $(F=43.32, \mathrm{p}<0.001)$ and seasons $(F=15.66, \mathrm{p}<0.001)$, and the interaction between site and season was significant $(F=2.44, \mathrm{p}=0.006)$. We then performed 1 -way ANOVAs for season only and site only, to examine the individual effects of these variables. A multiple-comparison test revealed that both Sandy Hook sites had significantly higher total chl a concentrations than did the
Long Island south shore bays (Tukey's test, p < 0.05). (The results for the multiple-comparison test for total and size fractionated chl a concentrations are presented Table S5 in the Supplement available at: http://www. int-res.com/journals/suppl/m387p179_app.pdf). Among the south shore bays, the eastern and central GSB had higher total chl a concentrations than the western GSB, Shinnecock Bay, and Middle Bay. Tukey's test also showed a significant difference in total chl a concentration between seasons, with peak chl a occurring in the summer (Tukey's test, $\mathrm{p}<0.05$ ). Spring and autumn total chl a concentrations were not significantly different (Tukey's test, p < 0.05).

The chl a concentration in the $>5 \mu \mathrm{m}$ size fraction differed between sites $(F=3.24, \mathrm{p}=0.01)$ but not season $(F=1.76, \mathrm{p}=0.18)$. The interaction between site and season was not significant $(F=1.13, \mathrm{p}=0.36)$. The multiple-comparison test revealed that the difference between sites was small with only 1 site, Sandy Hook

Table 2. Total chlorophyll a concentration ( $\mu \mathrm{g} \mathrm{chl} \mathrm{a} \mathrm{l}^{-1}$ ) and temperature $\left({ }^{\circ} \mathrm{C}\right)$ data for all sites from historical monitoring data $(\mathrm{see}$ 'Results' for details) and from our own sampling in 2000 and 2001; salinity data are from historical monitoring only. Data for December, January, and February are classified as winter; March, April, and May, as spring; June, July, and August, as summer; and September, October, and November, as autumn. Data are mean \pm SD (sample size). GSB: Great South Bay; nd: no data

\begin{tabular}{|c|c|c|c|c|c|}
\hline & \multicolumn{2}{|c|}{$-\operatorname{Chl} a\left(\mu g l^{-1}\right) \longleftarrow$} & \multicolumn{2}{|c|}{$\longrightarrow$ Temperature $\left({ }^{\circ} \mathrm{C}\right)-$} & \multirow{2}{*}{$\begin{array}{l}\text { Salinity } \\
\text { Historical }\end{array}$} \\
\hline & Historical & Present study & Historical & Present study & \\
\hline \multicolumn{6}{|c|}{ Sandy Hook Bay } \\
\hline Winter & $5.6 \pm 3.4(10)$ & nd & $5.1 \pm 1.8(22)$ & nd & $25.1 \pm 4.4(9)$ \\
\hline Spring & $11.1 \pm 10.6(9)$ & $34.8 \pm 32.2(4)$ & $11.3 \pm 3.8(36)$ & nd & $20.0 \pm 3.6(10)$ \\
\hline Summer & $14.8 \pm 11.1(17)$ & $37.2 \pm 22.6(10)$ & $20.8 \pm 4.0(33)$ & nd & $28.2 \pm 1.6(17)$ \\
\hline Autumn & $23.8 \pm 33.8(5)$ & $20.5 \pm 3.5(2)$ & $14.5 \pm 7.7(28)$ & nd & $25.4 \pm 1.9(7)$ \\
\hline \multicolumn{6}{|c|}{ Middle Bay } \\
\hline Winter & $8.0 \pm 6.9(63)$ & nd & $4.0 \pm 2.7(63)$ & nd & $30.9 \pm 1.3(63)$ \\
\hline Spring & $11.7 \pm 10.7(64)$ & $2.0 \pm 0.2(2)$ & $9.5 \pm 4.6(64)$ & $10.6 \pm 5.4(3)$ & $30.1 \pm 1.4(64)$ \\
\hline Summer & $11.5 \pm 11.2(66)$ & $11.2 \pm 10.7(6)$ & $21.8 \pm 2.9(66)$ & $23.4 \pm 2.3(6)$ & $29.6 \pm 2.2(66)$ \\
\hline Autumn & $6.2 \pm 6.4(63)$ & $2.7 \pm 2.3(2)$ & $14.6 \pm 4.6(63)$ & $14.7 \pm 10.3(2)$ & $30.6 \pm 1.3(63)$ \\
\hline \multicolumn{6}{|c|}{ Western GSB } \\
\hline Winter & $6.4 \pm 5.1(34)$ & nd & $4.1 \pm 2.3(132)$ & nd & $28.4 \pm 2.3(40)$ \\
\hline Spring & $6.8 \pm 5.9(56)$ & $2.5 \pm 0.8$ & $11.7 \pm 4.9(181)$ & $11.5 \pm 6.8(4)$ & $27.8 \pm 2.6(97)$ \\
\hline Summer & $11.5 \pm 15.9(62)$ & $5.6 \pm 1.8(7)$ & $24.2 \pm 2.4(234)$ & $23.4 \pm 2.6(6)$ & $28.2 \pm 1.9(104)$ \\
\hline Autumn & $4.7 \pm 3.7(58)$ & $2.6 \pm 1.0(3)$ & $15.7 \pm 6.1(199)$ & $16.6 \pm 4.6(3)$ & $29.0 \pm 1.5(98)$ \\
\hline \multicolumn{6}{|c|}{ Central GSB } \\
\hline Winter & $14.3 \pm 7.3(32)$ & nd & $3.7 \pm 2.3(67)$ & nd & $26.1 \pm 2.8(37)$ \\
\hline Spring & $9.0 \pm 5.3(50)$ & $4.7 \pm 1.0(2)$ & $11.5 \pm 4.8(106)$ & $12.2 \pm 6.9$ & $25.7 \pm 2.1(56)$ \\
\hline Summer & $17.4 \pm 8.1(74)$ & $14.6 \pm 6.9(7)$ & $24.3 \pm 2.3(148)$ & $24.2 \pm 2.9(6)$ & $26.6 \pm 2.3(99)$ \\
\hline Autumn & $13.7 \pm 6.9(55)$ & $8.1 \pm 3.6(3)$ & $15.4 \pm 6.2(105)$ & $16.1 \pm 5.2(3)$ & $26.8 \pm 1.8(59)$ \\
\hline \multicolumn{6}{|c|}{ Eastern GSB } \\
\hline Winter & $17.6 \pm 12.5(31)$ & nd & $3.5 \pm 2.1(63)$ & nd & $25.4 \pm 1.2(30)$ \\
\hline Spring & $10.7 \pm 8.2(48)$ & $9.1 \pm 4.0(2)$ & $10.7 \pm 4.7(102)$ & $11.7 \pm 6.6(4)$ & $24.5 \pm 1.7(62)$ \\
\hline Summer & $19.3 \pm 10.9(73)$ & $11.7 \pm 4.0(6)$ & $23.6 \pm 2.9(153)$ & $24.0 \pm 3.7$ & $24.2 \pm 2.5(86)$ \\
\hline Autumn & $20.4 \pm 9.5(54)$ & $7.3 \pm 0.9$ & $15.4 \pm 5.8(101)$ & $15.0 \pm 5.5(3)$ & $25.1 \pm 2.3(61)$ \\
\hline \multicolumn{6}{|c|}{ Shinnecock Bay } \\
\hline Winter & $6.5 \pm 6.2(49)$ & nd & $4.9 \pm 2.3(77)$ & nd & $30.2 \pm 1.5(46)$ \\
\hline Spring & $4.3 \pm 2.9(62)$ & $2.2 \pm 0.4(2)$ & $8.9 \pm 3.6(101)$ & $8.9 \pm 3.4(4)$ & $30.0 \pm 1.3(98)$ \\
\hline Summer & $9.2 \pm 7.7(89)$ & $3.0 \pm 3.5(6)$ & $20.9 \pm 3.0(154)$ & $20.3 \pm 2.9(6)$ & $29.9 \pm 1.1(110)$ \\
\hline Autumn & $9.4 \pm 7.2(72)$ & $2.9 \pm 2.2(3)$ & $15.4 \pm 4.4(112)$ & $14.5 \pm 5.0$ & $30.3 \pm 1.2(97)$ \\
\hline
\end{tabular}


906A, having a significantly greater (Tukey's test, $\mathrm{p}<$ 0.05 ) fraction of $>5 \mu \mathrm{m}$ chl a than Shinnecock Bay.

Although the percentage of chl a (Fig. 6) in the 2 to 5 $\mu \mathrm{m}$ fraction was similar between stations (19 to $33 \%$ ), ANOVA revealed a significant difference in chl a concentration in this size fraction between sites $(F=23.06$, $\mathrm{p}<0.001)$ but not seasons $(F=2.21, \mathrm{p}=0.11)$. The interaction between site and season was not significant $(F=$ $1.54, \mathrm{p}=0.11$ ). Sandy Hook sites had a significantly greater concentration of total chl $a$ in the 2 to $5 \mu \mathrm{m}$ size fraction than the south shore bays (Tukey's test, p < 0.05). Among the south shore bays, the central and eastern GSB sites had higher 2 to $5 \mu \mathrm{m}$ chl a concentrations than Shinnecock Bay and Middle Bay, but the western GSB only had higher concentrations than Shinnecock Bay and not Middle Bay.

There were notable differences in the distribution of $\mathrm{chl} a$ within the 0.7 to $2 \mu \mathrm{m}$ size fraction, with significant differences between sites $(F=40.86, \mathrm{p}<0.001)$ and seasons $(F=11.72, \mathrm{p}<0.001)$. The interaction between site and season was also significant $(F=2.74$, $\mathrm{p}=0.002$ ). Specifically, the amount of chl $a$ in the 0.7 to $2 \mu \mathrm{m}$ size range in the central and eastern GSB was significantly higher than at all other south shore bays (Middle Bay, Shinnecock Bay, and the western GSB; Tukey's test, $\mathrm{p}<0.05)$. The differences that we observed among sites were not entirely attributable to occurrences of a bloom of the picoplankter Aureococcus anophagefferens, however, since the central GSB was the only site with an extended and intense brown tide bloom (Table 3). Concentrations of 0.7 to $2 \mu \mathrm{m}$ chl $a$ in summer were higher than they were in spring (Tukey's test, $\mathrm{p}<0.05$ ), but the concentrations in spring and autumn did not differ significantly.

The seasonal total water chl a concentrations we measured (Table 2) were obtained over only 1 annual cycle (2000/2001), which was the relevant period for estimating the food resources available for the hard clams that we were sampling concurrently at these same locations. To obtain a longer term perspective on phytoplankton abundance, we analyzed total chl a data available from long-term monitoring sites that were adjacent to our hard clam study sites. These chl $a$ data were aggregated into the same 4 seasons that we used for our own data (Table 2). These multi-year seasonal averages (from 1988 to 2001) indicate that there was less overall variation in total chl a concentrations between locations than in the year we sampled these locations. The Sandy Hook spring time chl a concen-

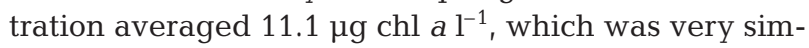
ilar to that in Middle Bay and the eastern GSB. The central GSB and western GSB values were lower $(9.0$

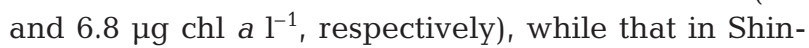
necock Bay was the lowest $\left(4.3 \mu \mathrm{g} \mathrm{chl} \mathrm{a} \mathrm{l}^{-1}\right)$. The average, long-term summer chl a concentrations were

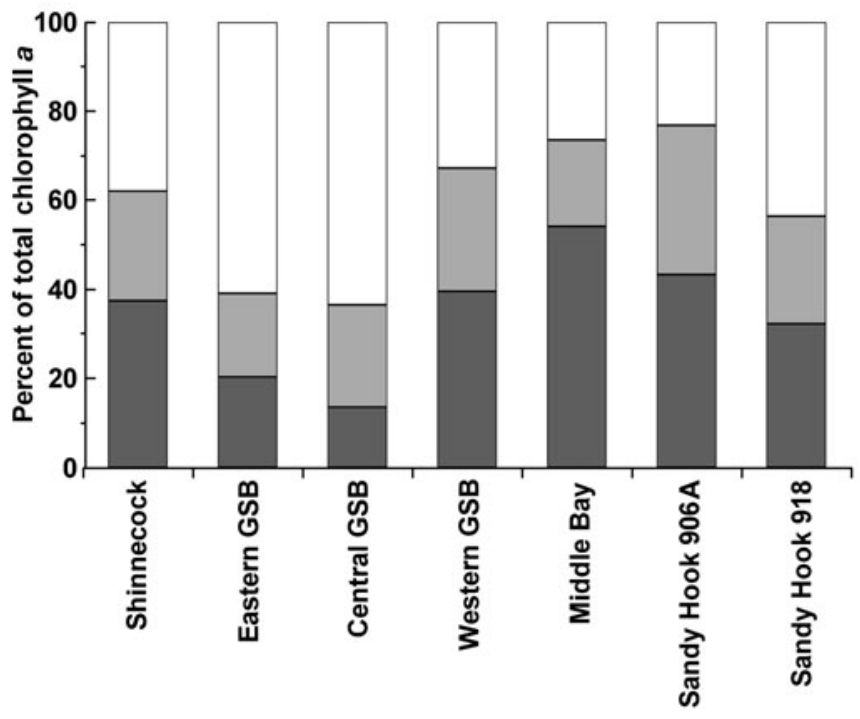

Fig. 6. Percent annual average chl a levels $\left(\mu g \mathrm{l}^{-1}\right)$ in 3 size fractions 0.7 to $2 \mu \mathrm{m}$ (white), 2 to $5 \mu \mathrm{m}$ (light grey), $>5 \mu \mathrm{m}$, (dark grey) at the 5 hard clam Mercenaria mercenaria sampling sites on the south shore of Long Island and 2 in Sandy Hook Bay during 2001. GSB: Great South Bay

highest in the eastern GSB, central GSB, and Sandy

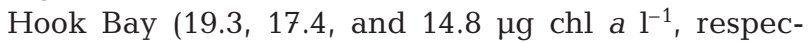
tively), with lower levels of 11.5, 11.5, and 9.2 for the western GSB, Middle Bay, and Shinnecock Bay, respectively. The comparison between these long-term data and our data indicates a high degree of interannual variability in the total chl a levels between sites. Despite this variability it is clear that both historically and during the present study Sandy Hook Bay, the eastern GSB, and central GSB always had the highest levels and Shinnecock Bay always had the lowest total chl a concentration.

Aureococcus anophagefferens concentrations of 35000 cells ml$^{-1}$ are considered to be the threshold above which deleterious effects on hard clam feeding become manifest (Bricelj et al. 2001). In order to obtain information on the occurrence of such brown tide blooms in 2000, prior to our initial sampling in autumn 2000, we obtained monitoring data from Suffolk County Department of Health Services. In 2000, a large $A$. anophagefferens bloom occurred throughout the GSB, with densities $>50000$ cells ml$^{-1}$ in the central and eastern GSB during the spring and summer months and in the western GSB during June (Table 3). Densities in autumn 2000 were not well documented, although Gobler et al. (2004) reported densities of $>35000$ cells ml$^{-1}$ in the central and eastern GSB during September 2000, which are within the range reported by Suffolk County at this time (Table 3). During 2001, our sampling indicated that brown tide cell counts were again above the threshold level in the central GSB for about 2 mo (early June through early 
Table 3. Aureococcus anophagefferens. Cell concentrations. Data from April to November 2000 were provided by the Suffolk County Department of Health Services. Data from 2001 are from the current study (mean \pm SD for 3 subsamples from each of 3 replicate $9 \mathrm{ml}$ water samples) at the 5 hard clam sampling sites on the south shore of Long Island. Values in bold are cell concentrations $>35000$ cells ml ${ }^{-1}$, which is the concentration at which toxic effects on hard clams become manifest (see 'Results' for details). A. anophagefferens was not detected in any of our samples from Sandy Hook Bay. To simplify this table, samples collected within $4 \mathrm{~d}$ of the mean date specified are listed together. GSB: Great South Bay; nd: no data

\begin{tabular}{|c|c|c|c|c|c|}
\hline Mean date & Shinnecock Bay & Eastern GSB & Central GSB & Western GSB & Middle Bay \\
\hline \multicolumn{6}{|l|}{2000} \\
\hline Apr 13 & nd & 60892 & 142094 & 17702 & nd \\
\hline Apr 27 & $<20$ & 267976 & 143656 & nd & nd \\
\hline May 17 & nd & 647764 & 61945 & 30308 & nd \\
\hline May 24 & nd & 296571 & 85850 & 215 & nd \\
\hline Jun 8 & nd & 689344 & 221153 & 161017 & nd \\
\hline Jun 20 & nd & nd & 1357309 & 304083 & nd \\
\hline Jun 28 & 14298 & 216304 & 601006 & nd & nd \\
\hline Jul 5 & nd & nd & 145698 & 6264 & nd \\
\hline Jul 10 & 7232 & nd & 371000 & nd & nd \\
\hline Jul 18 & nd & nd & 259825 & nd & nd \\
\hline Aug 1 & nd & nd & 160558 & nd & nd \\
\hline Aug 15 & 25029 & nd & 36798 & nd & nd \\
\hline Sep 6 & nd & 15495 & nd & nd & nd \\
\hline Nov 21 & nd & nd & 19336 & 251 & nd \\
\hline \multicolumn{6}{|l|}{2001} \\
\hline Mar 15 & 0 & $546 \pm 112$ & $955 \pm 49$ & $501 \pm 284$ & nd \\
\hline Apr 3 & $137 \pm 61$ & 0 & 0 & $532 \pm 105$ & $137 \pm 21$ \\
\hline Apr 23 & $137 \pm 0$ & $1092 \pm 283$ & $1229 \pm 236$ & $355 \pm 19$ & 0 \\
\hline May 18 & 0 & $819 \pm 133$ & $1138 \pm 209$ & $1065 \pm 42$ & $683 \pm 175$ \\
\hline Jun 5 & 0 & $63336 \pm 15443$ & $159332 \pm 52820$ & $3924 \pm 1886$ & $137 \pm 53$ \\
\hline Jun 24 & $137 \pm 61$ & $5392 \pm 1448$ & $773283 \pm 187353$ & $59645 \pm 16324$ & 0 \\
\hline Jul 8 & nd & $273 \pm 115$ & $35580 \pm 8264$ & $1065 \pm 57$ & $410 \pm 105$ \\
\hline Jul 15 & 0 & nd & $87005 \pm 8752$ & $177 \pm 67$ & $273 \pm 42$ \\
\hline Jul 24 & $137 \pm 160$ & $6893 \pm 2027$ & $69596 \pm 31282$ & $887 \pm 44$ & 0 \\
\hline Aug 7 & $273 \pm 105$ & $76713 \pm 11968$ & $115813 \pm 8654$ & $1065 \pm 126$ & $137 \pm 53$ \\
\hline Aug 28 & $410 \pm 52$ & $3890 \pm 1834$ & $20263 \pm 556$ & $1775 \pm 525$ & $683 \pm 105$ \\
\hline Sep 17 & 0 & 0 & $15015 \pm 273$ & $177 \pm 26$ & $\overline{0}$ \\
\hline
\end{tabular}

August), with extremely high densities in late June and a secondary bloom peak in August (Table 3). The eastern GSB generally had lower levels, with the exception of samples taken on 5 June and 7 August 2001, which had densities of $>50000$ cells $\mathrm{ml}^{-1}$. The western GSB showed high densities only on 24 June $\left(60000\right.$ cells $\left.\mathrm{ml}^{-1}\right)$. A. anophagefferens densities in Shinnecock Bay and Middle Bay never exceeded 1000 cells $\mathrm{ml}^{-1}$ during the 2000 to 2001 period (Table 3). We did not detect any $A$. anophagefferens cells in any sample we examined from Sandy Hook Bay, which is consistent with monitoring by the New Jersey Department of Environmental Protection.

There was substantial variability among our 5 Long Island sites in the quantity of suspended particulate organic material retained on GF/C filters (Fig. 7). Mean carbon and nitrogen content $\left(\mathrm{mg} \mathrm{l}^{-1}, \pm \mathrm{SD}\right)$ by date and sampling site and results from post hoc testing are presented in Tables S6 \& S7, respectively, both tables are in the Supplement available at: http://www. int-res.com/journals/suppl/m387p179_app.pdf. There were significant differences between sites in carbon $(F=44.72, \mathrm{p}<0.001)$ and nitrogen concentration $(F=$ $38.55, \mathrm{p}<0.001)$, and also significant seasonal variations for carbon $(F=19.77, \mathrm{p}<0.001)$ and nitrogen $(F=$ $6.04, p=0.003$ ). The interaction between site and season was not significant for either carbon or nitrogen. A multiple-comparison Tukey's test $(p<0.05)$ revealed that both the central and eastern GSB sites had significantly higher carbon and nitrogen concentrations than the other 3 SSB sites.

\section{DISCUSSION}

\section{Hard clam reproduction}

Long-term monitoring data and our sampling data indicate that there were significant differences in the quantity and composition of phytoplankton among the sites we studied in the SSBs of Long Island and in Sandy Hook Bay. Based on previous research on blue 

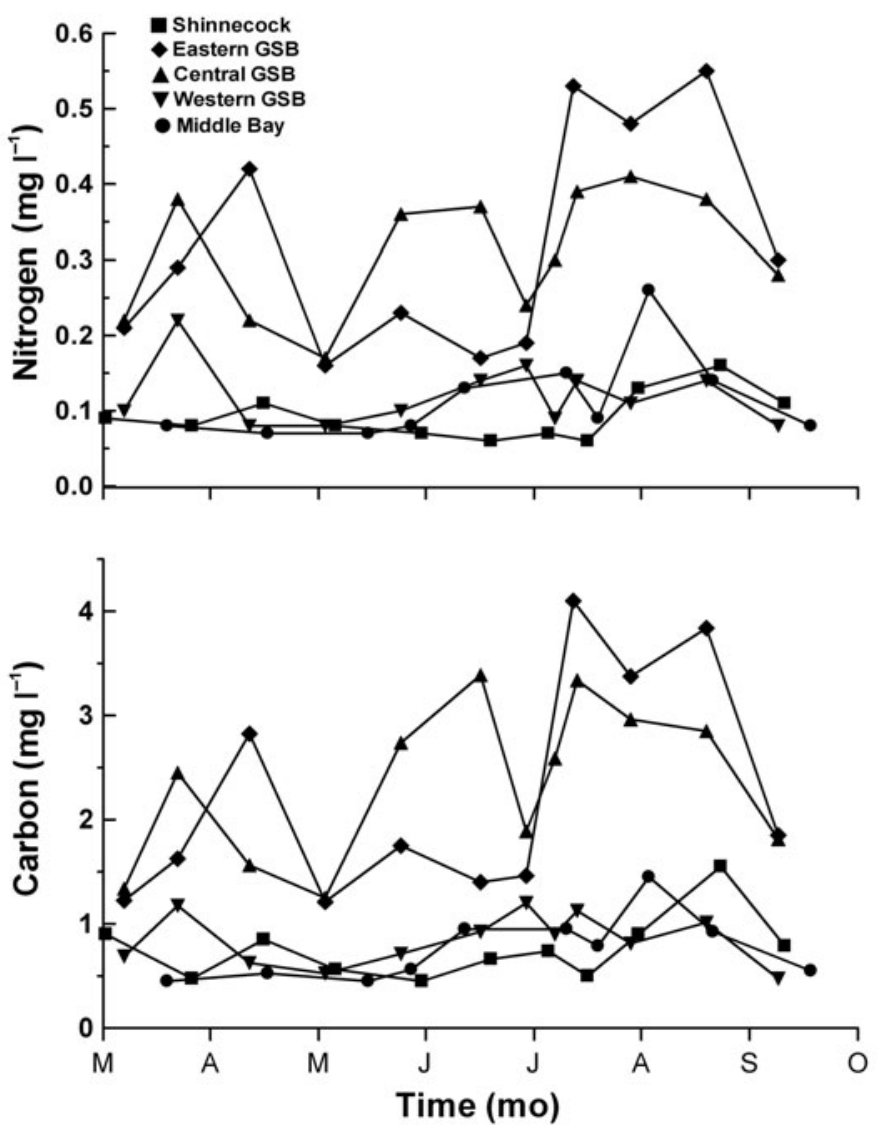

Fig. 7. Seston particulate organic nitrogen and carbon content $\left(\mathrm{mg} \mathrm{l}^{-1}\right)$ at the 5 hard clam Mercenaria mercenaria sampling sites on the south shore of Long Island during 2001. No samples were collected for the 2 sites in Sandy Hook Bay. Each point is the mean of 3 analyses. Error bars have been omitted to aid clarity. GSB: Great South Bay

mussels (Newell et al. 1982), we hypothesized that such changes in food resources might cause hard clams Mercenaria mercenaria to alter the timing of gamete ripening and spawning, hence causing larvae to be in the water column at a sub-optimal time. Such a disruption in reproductive processes could account for the reduced hard clam recruitment and declining stocks observed during the 1990s in some of these SSBs (Cerrato 2000, Kraeuter et al. 2005). Unexpectedly, we found that the timing of the maximum reproductive condition of female clams (Fig. 2) from each of the 5 sites in the SSBs did not vary, despite the appreciable differences in seston composition. Their reproductive patterns also did not differ from those of hard clams collected at 2 reference sites in Sandy Hook Bay, where abundant stocks have supported a robust fishery since the early 1990s. We used our methods to analyze histological slides prepared by Kassner (1982) for hard clams collected in 1979, thereby allowing a decadal time comparison of the reproductive cycle. The reproductive pattern of clams from the eastern
GSB in 1979 did not differ from the pattern we observed for hard clams from all 7 locations we sampled in 2001 (Fig. 2). We conclude that our initial hypothesis that clams at some locations would have reproductive cycles that differed from the normal pattern of peak gametogenic condition in early June followed by spawning through late July was not supported. Consequently, it appears unlikely that increased asynchrony in reproductive development and spawning is contributing to the decline in hard clam recruitment in any of the SSBs of Long Island.

Even though the timing of the peak reproductive condition did not vary between locations, there were significant differences in the magnitudes of the GVF and CI between hard clams from the 7 sites we sampled in 2000 and 2001 (Figs. 2 \& 3). These differences in CI cannot be explained by the significant differences $(p<0.001)$ in clam length between sites, because we found there was no statistical relationship between CI and clam length over the range of sizes that we examined. Furthermore, although clams from the eastern and central GSB were the smallest (54.8 and $63.3 \mathrm{~mm}$, respectively) we collected over the duration of the present study, those from the western GSB were the largest $(84.9 \mathrm{~mm})$. Yet the GVF and CI of hard clams from these 3 GSB sites were significantly lower during the period of peak reproductive activity than for clams from Shinnecock Bay, Middle Bay, and 2 sites in Sandy Hook Bay. These data, showing that hard clams from GSB have less tissue per unit shell size and that less of this tissue is comprised of eggs, suggest that these female clams will have lower individual fecundity. This is consistent with the observation that there is reduced recruitment to hard clam stocks in GSB (Kraeuter et al. 2005) compared with Shinnecock Bay, Middle Bay, and Sandy Hook Bay.

We analyzed hard clams collected in 1979 from the eastern GSB by Kassner (1982) to examine possible changes in the magnitude of the reproductive condition between 1979, when hard clam recruitment was at high levels, and 2001, a period when recruitment was considerably lower. Although the GVF of hard clams from the eastern GSB in 1979 appeared lower on average than that of clams from the 4 non-GSB sites in 2000 and 2001 (Fig. 2) and similar to the low GVF from the 3 GSB sites, in fact none of these differences were significant (Tukey, $\mathrm{p}=0.05$ ).

Unfortunately, the statistical power of our analysis of the Kassner data was low because we only had a relatively small number of samples from 1979 ( $\mathrm{n}=47$ ), whereas sample sizes for 2001 were 3 to 4 times larger ( $\mathrm{n}=147$ to 195 ). The size range (30 to $48 \mathrm{~mm}$ shell length) of clams collected by Kassner (1982) that we analyzed was smaller than that of the clams we sampled from the eastern GSB (40 to $76 \mathrm{~mm}$; mean $\pm \mathrm{SD}=$ 
$54.8 \pm 7.0$ ). Peterson (1983) reported that smaller and younger hard clams partition more energy to somatic growth rather than germinal production compared with larger ones, thereby enabling smaller animals to more rapidly reach a size refuge from predation. Therefore, although the hard clams collected by Kassner (1982) can be used to assess the timing of the reproductive cycle, it is possible that these clams may have exhibited a reduced GVF compared to the clams we collected simply because they were younger.

Hard clams collected from sites in GSB had CI values in autumn 2000 that were about $30 \%$ lower than those of hard clams from the other 4 sites (Fig. 3). This pattern of CI values being significantly lower for clams from the 3 GSB sites compared to our other 4 sampling sites was sustained throughout the entire sampling period in 2001. Unfortunately, Kassner (1982) did not measure the CI of the hard clams he collected from the eastern GSB in 1979, so we have no knowledge of possible long-term declines in the CI of clams living in GSB. Doall et al. (2008) measured the CI of large (average shell length $>62 \mathrm{~mm}$ ) hard clams over a number of years following transplantation into the central GSB from 2 sites in the western Long Island Sound (Fig. 1). They observed for 7 different batches of hard clams, transplanted over a period of $4 \mathrm{yr}$, that the CI of clams declined during the summer following transplantation to GSB. This decline was expected due to clam reproductive activity and spawning, but Doall et al. (2008) found that the CI of these transplanted clams did not, in subsequent years, regain the same high CI values exhibited at the time of transplantation. Interestingly, in one summer, the peak CI for 1 of the 7 transplanted stocks did regain the same high level measured initially at the time of transplantation. These CI data from our study and from that by Doall et al. (2008) indicate that some environmental factor in GSB is reducing the nutritional status of hard clams compared to other locations (e.g. Long Island Sound, Sandy Hook Bay, Middle Bay) where hard clam stocks are still flourishing. But the observation by Doall et al. (2008) that, at least once, transplanted hard clams did again attain a high CI value suggests that at certain times environmental conditions in GSB are conducive to hard clam growth.

In order to facilitate comparisons of hard clam reproductive activity between sites, we combined the GVF and CI into a novel index we called the 'relative reproductive output' (Fig. 4). This is not an absolute estimate of fecundity, such as would be obtained by spawning females and counting the number of eggs released. Even such a spawning technique will underestimate egg production in bivalve species, such as hard clams, that have continual egg development leading to a protracted spawning period over a period of months (Fig. 2). The RRO index we devised was based on our quantitative measurement of what percentage of the hard clam's visceral mass was occupied by eggs. These GVF values were then multiplied by the CI value for the same sampling time. Seasonal changes in CI (Fig. 3) are largely driven by changes in the amount of germinal tissue and stored nutrient reserves, as the mass of the somatic tissues (gills, adductor muscle, digestive gland, etc.) per unit shell size are less seasonally variable. Therefore, multiplying CI by the percent GVF produced a relative assessment of how much of the hard clam tissue at that sampling time was comprised of eggs. For the period of maximum reproductive activity (late April through late September), we integrated the RRO values (Fig. 4) that lay above the baseline winter values into a single value (Fig. 5), thereby permitting an overall comparison of hard clam reproductive output between sites that could be related to phytoplankton composition. The 3 sites with the lowest total RRO were in the central GSB, western GSB, and eastern GSB (Fig. 5). Paradoxically, the central GSB and eastern GSB had the highest spring and summer total whole-water chl a levels and organic nitrogen and carbon of any of the 5 sites in the SSBs (Table 2, Figs. $6 \&$ 7). These seston composition data suggest that clams at these GSB sites were exposed to the largest amounts of food, and thus one might expect that they would show maximum levels of reproductive output under such conditions. Upon further examination, however, it is apparent that the organic material in the seston at the central GSB and eastern GSB was largely contributed by small $(<5 \mu \mathrm{m})$ phytoplankton cells (Fig. 6).

\section{Phytoplankton composition}

Smaller phytoplankton are generally not as efficiently retained on the gill of hard clams as larger species (Grizzle et al. 2001), and the digestibility and nutritional value of picoplankton species are generally lower than those of nanoplanktonic microalgae (Langdon \& Newell 1996). A taxonomic shift in phytoplankton species composition that had an adverse effect on bivalves was first documented in GSB by Ryther (1954). He concluded that eastern oyster Crassostrea virginica stocks were adversely affected in the 1950s by extensive blooms of picoplanktonic algae, including Nannochloris atomus and Stichococcus sp., which were stimulated by duck farm fecal effluent containing high levels of ammonia and uric acid. These picoplanktonic species displaced nanoplanktonic algae with the consequence that the overall food quality of the phytoplankton for oysters was reduced. Laboratory studies using $N$. atomus as a food source showed that hard clams exhibit low assimilation efficiencies for this 
small $(<2 \mu \mathrm{m})$ chlorophyte and that during $6 \mathrm{wk}$ growth trials this alga did not support hard clam tissue growth (Bass et al. 1990). Similarly, the current preponderance of small phytoplankton, including Aureococcus anophagefferens, in GSB may be contributing to the lower reproductive output we observed for hard clams from the 3 sites in this bay. During 2 yr without brown tide blooms in Long Island's SSB (2004 and 2005), Weiss et al. (2007) found that adult hard clams transplanted to GSB had a significantly lower CI than those moved to Shinnecock Bay. Also consistent with our findings, Weiss et al. (2007) reported that the CIs of hard clams were significantly correlated with the densities of large diatoms (>5 $\mathrm{m})$, lending further credence to the idea that larger phytoplankton species are most nutritious for hard clams.

The differences we observed in the size composition of the phytoplankton between our various sampling sites, and hence the likely utility of the seston as a food resource, does not explain all of the changes in hard clam reproductive output we detected. For example, hard clam RRO in the western GSB was reduced to a low level similar to that in the central and eastern GSB, although overall phytoplankton composition in the western GSB did not differ significantly from that in Middle Bay, where hard clam stocks are still flourishing. However, one major difference between the sites in GSB and the other sites we sampled was the abundance of Aureococcus anophagefferens, the harmful picoplankter, which causes 'brown tide' (Bricelj \& Lonsdale 1997, Gobler et al. 2005). A. anophagefferens has an adverse effect on bivalves as it has been shown to reduce the feeding (Tracey 1988, Bricelj et al. 2001, Cerrato et al. 2004) and growth (Bricelj et al. 2004, Wazniak \& Glibert 2004, Padilla et al. 2006, Bricelj \& MacQuarrie 2007) of all life stages of many species of bivalves. In the central GSB during the spring, summer, and fall of 2000 and in the summer of 2001, concentrations of A. anophagefferens exceeded 35000 cells ml ${ }^{-1}$ (Table 3), a threshold which has been shown to inhibit juvenile hard clam feeding (Bricelj et al. 2001). Cell densities also exceeded this level on some sampling dates during the spring and summer of 2000 and the summer of 2001 in the eastern and western GSB (Table 3). Our data on brown tide blooms are consistent with the Suffolk County Department of Health Services' analyses that reported a brown tide bloom at our central GSB site beginning in mid-May 2001 and persisting into July. We hypothesize that, although the overall seston composition in the western GSB in 2001 was adequate as a food resource to support hard clams, there were sufficient $A$. anophagefferens cells present to inhibit hard clam feeding in 2000 and 2001. The incidence of brown tide blooms during 2000, before we initiated our field collection of clams in the autumn of 2000, likely reduced the feeding activity of clams in GSB. This is a plausible explanation for the significantly lower CIs we found for clams from the 3 sites in GSB compared with those for clams collected from the other 4 sites (Fig. 3). This overall reduction in CIs was responsible for the low estimated RRO for hard clams from the 3 GSB sites.

We compiled the long-term data of Aureococcus anophagefferens cell abundances (Table 4) from water-quality monitoring sites closest to the locations where we sampled hard clams (SCDHS 2005). The sites in the western, central, and eastern GSB had bloom concentrations of A. anophagefferens present at $\sim 23$ to $39 \%$ of the times sampled during summer. Whereas in Shinnecock Bay, bloom concentrations were present only $15 \%$ of the time. There are no comprehensive water-quality monitoring data available for Middle Bay, but sporadic sampling by the County of

Table 4. Aureococcus anophagefferens. Frequency of occurrence of blooms (defined as cell concentrations $>35000 \mathrm{cells} \mathrm{ml}^{-1}$ ) of brown tide at the sampling sites on the south shore of Long Island. Historical data from Suffolk County Department of Health Services (1985 to 2001) and data obtained during the present study (2001). No data (nd) were available for Middle Bay because it has only been sporadically sampled by Suffolk County Department of Health Services. A. anophagefferens has not been detected in Sandy Hook Bay. 'Years with blooms' represents the number of years monitored $(\mathrm{N})$ in which A. anophagefferens cell densities exceeded the bloom threshold at least at 1 sampling time; this value is also expressed as a percentage. 'Sampling times with blooms' indicates how many of the total sampling times (n) had A. anophagefferens cell densities that exceeded the bloom threshold; this value is also expressed as a percentage. GSB: Great South Bay

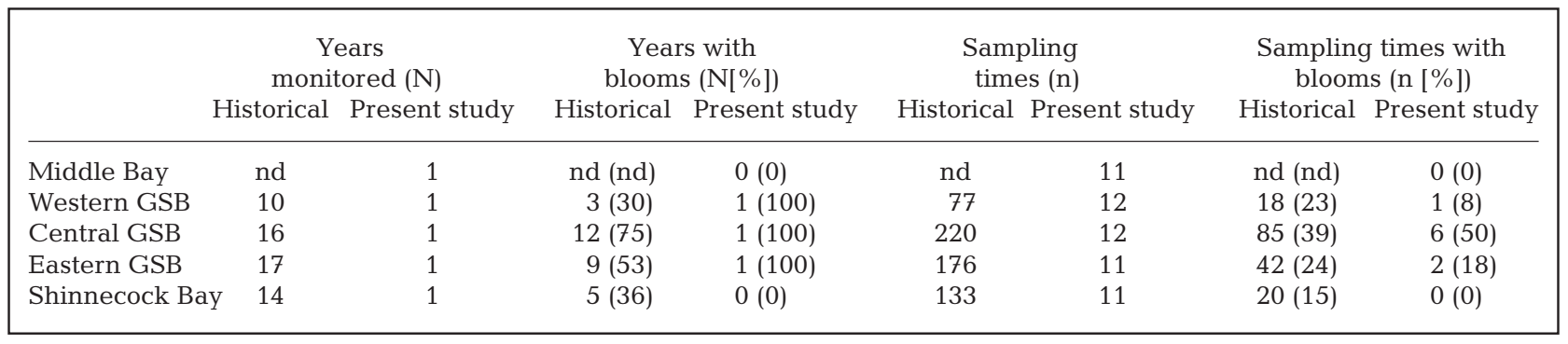


Suffolk (R. Waters, SCDHS, pers. comm.), coupled with our observations, indicate an absence of brown tide blooms in Middle Bay. Similarly, brown tide blooms have never been reported for Sandy Hook (Gastrich et al. 2004), likely because that bay is open to the Atlantic Ocean and hence well flushed. These long-term data on the occurrence of brown tide blooms, and our own observations, support the hypothesis that the low recruitment of hard clams in GSB is due, at least in part, to the inhibition of hard clam feeding activity associated with chronic blooms of brown tide (Bricelj \& Lonsdale 1997, Gobler et al. 2005).

The differences we observed in phytoplankton size composition and the development of blooms of Aureococcus anophagefferens are likely, in part, associated with anthropogenic organic nutrient enrichment (Gobler et al. 2002, 2004, 2005, Glibert et al. 2005). These effects of nutrient enrichment may be exacerbated by a reduction in top-down grazing control due to a decline in benthic suspension feeders, including hard clams (Cerrato et al. 2004, Wall et al. 2008), and low and differential grazing pressure by zooplankton (Gobler et al. 2002, Caron et al. 2004, Deonarine et al. 2006). It is thought that such harmful algal blooms are increasing in distribution and frequency worldwide (Shumway 1990, Cloern 2001) to the detriment of resident organisms (Sunda et al. 2006). The chemical form of a nutrient has a pronounced effect on phytoplankton species composition. Gobler et al. (2002) reported that A. anophagefferens has a competitive advantage over other phytoplankton species because it can metabolize dissolved organic nitrogen in addition to inorganic nitrogen. The total dissolved nitrogen and phosphorus pools in GSB are composed primarily (92 and 100\%, respectively) of organic forms (Lonsdale et al. 2006), suggesting this system is ideally suited for phytoplankton such as $A$. anophagefferens. Moreover, the ratio of total dissolved nitrogen to silicate in this bay is $14: 1$ (Lonsdale et al. 2006), indicating that nutritionally valuable diatoms, which require a 1:1 N:Si molar ratio, may be at a competitive disadvantage in GSB compared to mixotrophic and/or non-silica-requiring phytoplankton (Brzezinski 1985, Cloern 2001, Gobler et al. 2006). Such an imbalance in the total dissolved nitrogen to silicate ratio is likely caused by anthropogenic nutrient loading and has been cited as a cause of regime shifts in phytoplankton communities globally (Smayda 1990, Cloern 2001).

The high abundance of other picophytoplankton species in addition to Aureococcus anophagefferens in GSB during summer may also be related to high ambient water temperatures. Summer temperatures in GSB were nearly $3^{\circ} \mathrm{C}$ greater than at all other sites (Table 2), likely due in part to the long residence time of this shallow lagoon ( 3 mo; Wilson et al. 1991) compared to the other, more open and well-flushed sites we sampled. High temperatures yield higher metabolic rates of algae (Goldman \& Carpenter 1974), leading to rapid depletion of nutrients during summer months (Lively et al. 1983) and selecting for the dominance of small phytoplankton whose nutrient assimilation kinetics are best suited to a low-nutrient environment (Raven \& Kubler 2002). As such, increasing flushing rates of GSB and thereby decreasing temperatures via a breach in the barrier island chain might discourage the growth of picophytoplankton and, in turn, increase the success of hard clams in this system.

There is still incomplete understanding of the range of toxic compounds produced by microalgae and their effect on suspension-feeding organisms. Diatom species are generally considered to be a highly nutritious class of microalgae, and many species have been shown to promote survival and growth of bivalve larvae and adults (Langdon \& Newell 1996, Weiss et al. 2007). However, field and laboratory studies indicate that polyunsaturated aldehydes, which are produced by some diatom species during stationary growth phase (Wichard et al. 2005), can interfere with successful egg fertilization and larval development of copepods, hence reducing overall copepod reproductive success (e.g. Miralto et al. 1999, Ianora et al. 2004, Vargas et al. 2006). Similar studies on the effects of diatoms rich in aldehydes on bivalve molluscs have not yet been performed to see if fertilization and embryo development are adversely affected in a similar manner. It is becoming apparent that many species of microalgae, when growing under certain specific conditions, can produce chemicals that can exert an adverse effect on suspension-feeding invertebrates. Further research is required to determine if any of the microalgae that are now favored by the nutrient regime in GSB are producing chemicals that can reduce hard clam egg fertilization success or subsequent larval development, thereby contributing to the observed decline in hard clam recruitment.

\section{Summary}

It is apparent that anthropogenic changes in nutrient inputs to the GSB and the concurrent loss in filtration pressure by bivalves are now favoring the production of picoplankton, and especially the harmful alga Aureococcus anophagefferens (Gobler et al. 2005). These changes in phytoplankton composition may alter the quality of the seston as a food resource for hard clams and inhibit their feeding activity. Consequently, the nutritional status of hard clams in GSB appears to be compromised, leading to our observa- 
tions of the depressed CI and reproductive output of these stocks of hard clams relative to those in Middle Bay and Sandy Hook Bay. In these 2 latter systems recruitment is still robust, larger species of phytoplankton dominate, and brown tides do not occur. In addition to the effects that changes in phytoplankton community composition have on the reproductive output of adult hard clams, the growth of any clam larvae that are produced is also severely reduced by brown tide blooms (Padilla et al. 2006, Bricelj \& MacQuarrie 2007). The severe adverse effects of $A$. anophagefferens on different stages in the life cycle of the hard clam are consistent with the hypothesis that brown tide blooms are a prime cause of the continuing decline in hard clam recruitment in GSB (Gobler et al. 2005). Management options for improving conditions for hard clam recruitment are limited. Primarily, it will require watershed-level changes in factors influencing phytoplankton species composition, such as curbing total nutrient inputs and altering flushing and/or circulation patterns in GSB.

Acknowledgements. We are grateful to L. Ragone-Calvo and colleagues at Virginia Institute of Marine Science for preparing the histological slides. Logistical assistance was generously provided by G. Flimlin, J. Harry, B. Bialick, R. McIntyre, D. Getz, and W. Caldwell. J. Kassner kindly made available his archived slides. Water-quality data were generously supplied by M. Foley, B. Connell, and M. Waters. Numerous undergraduate students at Southampton College participated in field sampling. This research was funded under Award NA96FL0279 from the NOAA National Sea Grant College to New York Sea Grant Program. The United States government is authorized to publish reprints of this work notwithstanding any copyright notations hereon.

\section{LITERATURE CITED}

Anderson DM, Kulis DM, Cetta CM, Cosper EM (1989) Immunofluorescent detection of the brown tide organism, Aureococcus anophagefferens. In: Cosper EM, Bricelj VM, Carpenter EJ (eds) Novel phytoplankton blooms: causes and impacts of recurrent brown tides and other unusual blooms. Springer, New York, p 213-228

Anderson DM, Glibert PM, Burkholder JM (2002) Harmful algal blooms and eutrophication: nutrient sources, composition and consequences. Estuaries 25:704-726

Bass AE, Malouf RE, Shumway SE (1990) Growth of northern quahogs (Mercenaria mercenaria (Linnaeus, 1758) fed on picoplankton. J Shellfish Res 9:299-307

Bayne BL (1975) Reproduction in bivalve molluscs under environmental stress. In: Vernberg FJ (ed) Physiological ecology of estuarine organisms. University of South Carolina Press, Columbia, SC, p 259-277

Bayne BL (1976) Aspects of reproduction in bivalve molluscs. In: Wiley ML (ed) Estuarine processes, Vol 1. Academic Press, New York, p 432-448

Bayne BL, Brown DA, Burns K, Dixon DR and others (1985) The effects of stress and pollution on marine animals. Praeger, Westport, CT
Box GEP, Cox DR (1964) An analysis of transformations (with discussion). J R Stat Soc B 26:211-252

Bricelj VM, Lonsdale DJ (1997) Aureococcus anophagefferens: causes and ecological consequences of brown tides in US mid-Atlantic coastal water. Limnol Oceanogr 42: 1023-1038

Bricelj VM, MacQuarrie SP (2007) Effects of brown tide (Aureococcus anophagefferens) on hard clam Mercenaria mercenaria larvae and implications for benthic recruitment. Mar Ecol Prog Ser 331:147-159

> Bricelj VM, MacQuarrie SP, Schaffner R (2001) Differential effects of Aureococcus anophagefferens isolates ('brown tide') in unialgal and mixed suspensions on bivalve feeding. Mar Biol 139:605-616

Bricelj VM, MacQuarrie SP, Smolowitz R (2004) Concentration-dependent effects of toxic and non-toxic isolates of the brown tide alga Aureococcus anophagefferens on growth of juvenile bivalves. Mar Ecol Prog Ser 282:101-114

Brzezinski MA (1985) The Si:C:N ratio of marine diatoms: interspecific variability and the effect of some environmental variables. J Phycol 21:347-357

Caron DA, Gobler CJ, Lonsdale DJ, Buck NJ, Cerrato RM and others (2004) Microbial herbivory on the brown tide alga, Aureococcus anophagefferens: results from natural ecosystems, mesocosms and laboratory experiments. Harmful Algae 3:439-457

Cerrato R (2000) Perspectives on possible factors influencing the abundance of hard clams. In: Schlenk CG (ed) Workshop on hard clam population dynamics. Research priorities for the south shore of Long Island. New York Sea Grant, Stony Brook, NY

> Cerrato RM, Caron DA, Lonsdale DJ, Rose JM, Schaffner RA (2004) Effect of the northern quahog Mercenaria mercenaria on the development of blooms of the brown tide alga Aureococcus anophagefferens. Mar Ecol Prog Ser 281: 93-108

Cloern JE (2001) Our evolving conceptual model of the coastal eutrophication problem. Mar Ecol Prog Ser 210: 223-253

Crosby MP, Gale LD (1990) A review and evaluation of bivalve condition index methodologies with a suggested standard method. J Shellfish Res 9:233-237

> Deonarine SN, Gobler CJ, Lonsdale DJ, Caron DA (2006) The role of zooplankton in the occurrence of harmful brown tide blooms (Aureococcus anophagefferens) in US midAtlantic estuaries. Aquat Microb Ecol 44:181-195

> Doall MH, Padilla DK, Lobue CP, Clapp C, Webb AR, Hornstein J (2008) Evaluating northern quahog (=hard clam, Mercenaria mercenaria L.) restoration: Are transplanted clams spawning and reconditioning? J Shellfish Res 27: 1069-1080

Eversole AG (2001) Reproduction in Mercenaria mercenaria. In: Kraeuter JN, Castagna M (eds) Biology of the hard clam. Elsevier Science, New York, p 221-260

Gastrich MD, Lathrop R, Haag S, Weinstein MP, Danko M, Caron DA, Schaffner R (2004) Assessment of brown tide blooms, caused by Aureococcus anophagefferens, and contributing factors in New Jersey coastal bays: 20002002. Harmful Algae 3:305-320

Glibert PM, Seitzinger S, Heil CA, Burkholder JM, Parrow MW, Codispoti LA, Kelly V (2005) The role of eutrophication in the global proliferation of harmful algal blooms: new perspectives and new approaches. Oceanography 18: 198-209

Gobler CJ, Renaghan MJ, Buck NJ (2002) Impacts of nutrients and grazing mortality on the abundance of Aureococcus anophagefferens during a New York brown tide 
bloom. Limnol Oceanogr 47:129-141

Gobler CJ, Boneillo GE, Debenham CJ, Caron DA (2004) Nutrient limitation, organic matter cycling, and plankton dynamics during an Aureococcus anophagefferens bloom. Aquat Microb Ecol 35:31-43

Gobler CJ, Lonsdale DJ, Boyer GL (2005) A review of the causes, effects, and potential management of harmful brown tide blooms caused by Aureococcus anophagefferens (Hargraves et Sieburth). Estuaries 28:726-749

Gobler CJ, Sañudo-Wilhelmy SA, Buck NJ, Sieracki ME (2006) Nitrogen and silicon limitation of phytoplankton communities across an urban estuary: the East RiverLong Island Sound system. Estuar Coast Shelf Sci 68: $127-138$

Goldman JC, Carpenter EJ (1974) A kinetic approach to the effect of temperature on algal growth. Limnol Oceanogr 19:756-766

Grizzle RE, Bricelj VM, Shumway SE (2001) Physiological ecology of Mercenaria mercenaria. In: Kraeuter JN, Castagna M (eds) Biology of the hard clam. Elsevier Science, New York, p 305-382

Ianora A, Miralto A, Poulet SA, Carotenuto Y and others (2004) Aldehyde suppression of copepod recruitment in blooms of a ubiquitous planktonic diatom. Nature 429: 403-407

Kassner J (1982) The gametogenic cycle of the hard clam, Mercenaria mercenaria, from different locations in the Great South Bay, New York. MS thesis, State University of New York at Stony Brook, Stony Brook, NY

Kassner J (2000) Overview of the status of hard clams in the SSER. In: Schlenk CG (ed) Workshop on hard clam population dynamics. Research priorities for the south shore of Long Island. New York Sea Grant, Stony Brook, NY, p 5-8

Kassner J, Malouf RE (1982) An evaluation of 'spawner transplants' as a management tool in Long Island's hard clam fishery. J Shellfish Res 2:165-172

Kraeuter JN, Buckner S, Powell EN (2005) A note on a spawner-recruit relationship for a heavily exploited bivalve: the case of northern quahogs (hard clams), Mercenaria mercenaria in Great South Bay New York. J Shellfish Res 24:1043-1052

Laetz CA (2002) Reconstruction of growth of hard clams, Mercenaria mercenaria, under brown tide conditions. MS thesis, State University of New York at Stony Brook, Stony Brook, NY

Langdon CJ, Newell RIE (1996) Digestion and nutrition of larvae and adults. In: Kennedy VS, Newell RIE, Eble A (eds) The eastern oyster, Crassostrea virginica. Maryland Sea Grant Publication, College Park, MD, p 231-270

Lively J, Kaufman Z, Carpenter EJ (1983) Phytoplankton ecology of a barrier island estuary: Great South Bay, New York. Estuar Coast Shelf Sci 16:51-68

Lonsdale DJ, Greenfield DI, Hillebrand EM, Nuzzi R, Taylor GT (2006) Microplanktonic community composition and trophic structure in two Long Island, New York, USA, embayments. J Plankton Res 28:891-905

MacKenzie CL Jr (2003) Comparison of invertebrate abundances in four bays of the northeastern United States: two bays with sparse quahogs and two bays with abundant quahogs. Northeast Fish. Sci. Cent. Ref. Doc. 03-10, NEFSC, Woods Hole, MA. Available at: www.nefsc.noaa. gov/publications/crd/crd0310/index.htm

MacKenzie CL Jr, Morrison A, Taylor DL, Burrell VG Jr, Arnold WS, Wakida-Kusunoki AT (2002) Quahogs in eastern North America. II. History by province and state. Mar Fish Rev 64:1-64

Miralto A, Barone G, Romano G, Poulet SA and others (1999)
The insidious effect of diatoms on copepod reproduction. Nature 402:173-176

Newell RIE, Hilbish TJ, Koehn RK, Newell CJ (1982) Temporal variation in the reproductive cycle of Mytilus edulis (Bivalvia, Mytildae) from localities on the east coast of North America. Biol Bull 162:299-310

Nixon SW (1995) Coastal marine eutrophication-a definition, social causes, and future concerns. Ophelia 41: $199-219$

NYSDEC (New York State Department of Environmental Conservation) (2008) Annual commercial shellfish landings for New York state, 1946-2007. NYSDEC, East Setanket, NY

> Padilla DK, Doall MH, Gobler CJ, Hartson A, O'Boyle K (2006) Brown tide alga, Aureococcus anophagefferens, can affect growth but not survivorship of Mercenaria mercenaria larvae. Harmful Algae 5:736-748

Peterson CH (1983) A concept of quantitative reproductive senility: Application to the hard clam Mercenaria mercenaria (L.)? Oecologia 58:164-168

Raven JA, Kubler JE (2002) New light on the scaling of metabolic rate with the size of algae. J Phycol 38:11-16

> Ryther JH (1954) The ecology of phytoplankton blooms in Moriches Bay and Great South Bay, Long Island, New York. Biol Bull 106:198-209

SCDHS (Suffolk County NY Department of Health Services) (2005) Annual report on water quality in Suffolk County's coastal waters. Office of Ecology, SCDHS, Yaphank, NY

> Shumway SE (1990) A review of the effects of algal blooms on shellfish and aquaculture. J World Aquacult Soc 21: 65-104

Sieracki ME, Gobler CJ, Cucci TL, Thier EC, Gilg IC, Keller MD (2004) Pico- and nanoplankton dynamics during bloom initiation of Aureococcus in a Long Island, NY bay. Harmful Algae 3:459-470

Smayda TJ (1990) Novel and nuisance phytoplankton blooms in the sea: evidence for a global epidemic. In: Graneli E, Sundstrom B, Edler L, Anderson DM (eds) Toxic marine phytoplankton. Elsevier, New York, p 29-40

Strickland JDH, Parsons TR (1972) A practical handbook of seawater analysis. Bull Fish Res Board Can 167:1-311

Sunda WG, Graneli E, Gobler CJ (2006) Positive feedback and the development and persistence of ecosystem disruptive algal blooms. J Phycol 42:963-974

- Tracey GA (1988) Feeding reduction, reproductive failure, and mortality in Mytilus edulis during the 1985 'brown tide' in Narragansett Bay, Rhode Island. Mar Ecol Prog Ser 50:73-81

> Vargas CA, Escribano R, Poulet S (2006) Phytoplankton food quality determines time windows for successful zooplankton reproductive pulses. Ecology 87:2992-2999

> Wall CC, Peterson BJ, Gobler CJ (2008) Facilitation of seagrass Zostera marina productivity by suspension-feeding bivalves. Mar Ecol Prog Ser 357:165-174

> Wazniak CE, Glibert PM (2004) Potential impacts of brown tide, Aureococcus anophagefferens, on juvenile hard clams, Mercenaria mercenaria, in the coastal bays of Maryland, USA. Harmful Algae 3:321-329

Weiss MB, Curran PB, Peterson BJ, Gobler CJ (2007) The influence of plankton composition and water quality on hard clam (Mercenaria mercenaria L.) populations across Long Island's south shore lagoon estuaries (New York, USA). J Exp Mar Biol Ecol 345:12-25

- Wichard T, Poulet SA, Halsband-Lenk C, Albaina A, Harris R, Liu DY, Pohnert G (2005) Survey of the chemical defense potential of diatoms: screening of fifty one species for alpha, beta, gamma, delta-unsaturated aldehydes. 
J Chem Ecol 31:949-958

Wilson RE, Wong KC, Carter HH (1991) Aspects of circulation and exchange in Great South Bay. In: Schubel JR, Bell TM

Carter HH (eds) The Great South Bay. SUNY Press, Albany, NY, p 33-42

Zar JH (1999) Biostatistical analysis, 4th edn. Prentice-Hall,

Editorial responsibility: Matthias Seaman,

Oldendorf/Luhe, Germany
Upper Saddle River, NJ

Zimmer BJ (2004) Raritan and Sandy Hook Bays sanitary survey report 1997-2000. Bureau of Marine Water Monitoring, NJ Dept of Environmental Protection, Leedss Point, NJ, p 7-18. Available at: www.nj.gov/dep/bmw/Reports/ ne1-01.pdf

Submitted: October 17, 2008; Accepted: April 24, 2009 Proofs received from author(s): July 1, 2009 